\title{
Long-stored soil carbon released by prehistoric land use: Evidence from compound-specific radiocarbon analysis on Soppensee lake sediments
}

\author{
Merle Gierga ${ }^{a}$, Irka Hajdas ${ }^{b}$, Ulrike J. van Raden ${ }^{a}$, Adrian Gilli $^{a}$, Lukas Wacker ${ }^{b}$, Michael Sturm $^{c}$, Stefano \\ M. Bernasconi ${ }^{a}$, Rienk H. Smittenberg ${ }^{d}$ \\ a Department of Earth Sciences, ETH Zürich, Sonneggstrasse 5, 8092 Zürich, Switzerland \\ ${ }^{\mathrm{b}}$ Laboratory of Ion Beam Physics, ETH Zürich, 8093 Zürich, Switzerland \\ ${ }^{c}$ Department of Surface Waters Research and Management, Eawag, Swiss Federal Institute of Aquatic \\ Science and Technology, 8600 Dübendorf, Switzerland \\ d Department of Geological Sciences, Stockholm University, 10691 Stockholm, Sweden
}

\section{Abstract}

Compound-specific radiocarbon $\left({ }^{14} \mathrm{C}\right)$ analyses allow studying the fate of individual biomarkers in ecosystems. In lakes with small catchments, terrestrial biomarkers have the potential to be used for the dating of sediments that lack the traditionally targeted terrestrial macrofossils, if the specific organic compounds are deposited soon after production. On the other hand, if the biomarkers have been stored for a significant amount of time in the soils of the catchment before transported to the lake, their age can be used to reconstruct changes in average residence time of organic material on land through time. Here we present a study based on compound-specific ${ }^{14} \mathrm{C}$ analysis of the sedimentary record of Lake Soppensee, Switzerland, targeting long-chain $n$-alkanes of exclusive terrigenous origin, and comparing them with sediment ages obtained by high-resolution macrofossil dating. Additionally, we measured ${ }^{14} \mathrm{C}$ ages of bulk organic matter and carbonate samples to assess the hard water effect. Prior to 3100 cal BP $n$-alkanes had about the same age as the sediment or they were slightly older, indicating that the vast majority of the terrestrial organic carbon transported to the lake had a short residence time on land. In the samples younger than 3100 cal BP an increasing offset is observed, indicating liberation of old buried soil organic matter that must have accumulated over the previous millennia. 
Our results indicate that as long as stable ecosystem conditions have prevailed, the distribution and isotopic composition of the $n$-alkanes can be used as environmental proxies in small catchments with limited surface runoff, confirming a few earlier studies.

\section{Keywords}

Compound-specific radiocarbon analysis (CSRA), lacustrine sediments, Soppensee/ Switzerland, long-chain $n$-alkanes 


\section{Introduction}

Radiocarbon $\left({ }^{14} \mathrm{C}\right)$ dating is a fundamental tool for paleolimnological investigations of lacustrine sedimentary records that have been formed during the last 50,000 years. Its paramount importance lies in the establishment of reliable age models for the correlation of events and intervals in order to establish leads and lags in the response of different components of the climate system to external forcing. Terrestrial macrofossils are considered to be the most adequate material for ${ }^{14} \mathrm{C}$ dating of lacustrine sediments (e.g. Hajdas et al., 1995; Hou et al., 2010; Törnqvist et al., 1992), as this type of organic material (OM) records the atmospheric carbon dioxide $\left(\mathrm{CO}_{2}\right)$ and is generally rapidly transported and preserved in lake sediments. However, terrestrial macrofossils often cannot be found in sufficient amounts in the sediment. Dating of total organic carbon (TOC) in sediments is in many cases not an alternative, as this often results in significantly older ages than the age of sediment deposition (e.g. Benoit et al., 1979; Turney et al., 2000 and references therein). This is due to the heterogeneous nature of sedimentary TOC, consisting of a variety of different components derived both from allochthonous and autochthonous sources and of minerogenic and biogenic origin. Where old, ${ }^{14} \mathrm{C}$-free, calcareous bedrock is present in the catchment, the so-called 'hard water effect' is observed (e.g. Deevey et al., 1954; Shotton, 1972). Limestone dissolution reduces the radiocarbon content of the dissolved inorganic $\mathrm{C}$ pool, which is incorporated in photosynthetic aquatic plants and algae, also resulting in older ages of TOC. These problems can be circumvented focusing on source-specific organic compounds, the co-called biomarkers (e.g. Mollenhauer and Rethemeyer, 2009). Radiocarbon dating of specific biomarkers have been made possible by new developments in modern highprecision accelerator mass spectrometry (AMS) techniques, which allowed the introduction of compound-specific radiocarbon analysis (CSRA, Eglinton et al., 1996). Applying this technique to biomarkers from higher plant waxes can be an adequate 
alternative to the use of terrestrial macrofossils, as they are of unique origin and usually present in quantities large enough for ${ }^{14} \mathrm{C}$ analysis. There have been a few studies that measured the ${ }^{14} \mathrm{C}$ content of higher plant waxes (e.g. long-chain $n$ alkanes or $n$-fatty acids) in sediments. However, significantly pre-aged $n$-alkanes and $n$-fatty acids have been reported suggesting residence and transport times that range between a few hundred to a few thousand years, depending on the investigated setting (e.g. Eglinton et al., 1997; Galy and Eglinton, 2011; Mollenhauer et al., 2007; Smittenberg et al., 2006). Most CSRA studies to date have focused on using CSRA to investigate residence times and transport mechanisms of organic material from large catchments on land to the ocean (e.g. Drenzek et al., 2007; Pearson and Eglinton, 2000; Smittenberg et al., 2006). There are only few publications applying CSRA to sediment records of lakes with small catchments of just a few $\mathrm{km}^{2}$ (e.g. Douglas et al., 2014; Hou et al., 2010; Jones et al., 2013; Uchikawa et al., 2008). Uchikawa et al. (2008) argued that, in contrast to the large-scale systems, pre-aging of terrestrial biomarkers is insignificant in lakes with small catchments as transport times of $O C$ between the terrestrial system and the lake can be neglected. These authors successfully constructed an age-model for the Ordy Pond, O'ahu, Hawaii, using the long-chain $n$-alkanes $\mathrm{C}_{27}, \mathrm{C}_{29}, \mathrm{C}_{31}$ and $\mathrm{C}_{33}$. Hou et al. (2010) came to the same conclusion using lignin-derived phenols to establish chronologies for small lake sediments, and Jones et al. (2013) used an $n$-alkane-based chronology that matched well with pollen-based marker horizons present in the Greek lake loannina. However, even though the latter three studies demonstrated the potential of terrestrial-derived biomarkers for dating sediments of small watershed lakes, Douglas et al. (2014) demonstrated that plant waxes in surface sediments of small lakes in Central America were considerably pre-aged. Overall, these studies show that the potential of terrestrial derived biomarkers for dating sediments is still poorly constrained and it is not clear weather a pre-aging might be system dependent and/or varies through time. 
In this study we performed CSRA of long-chain $n$-alkanes, as well as conventional

${ }^{14} \mathrm{C}$ analyses on TOC and carbonates of the extremely well-dated sedimentary record of Lake Soppensee (Hajdas and Michczynski, 2010), which allows the direct comparison of the age of various sediment components with an age-model based on an extensive dataset with more than 80 macrofossil ${ }^{14} \mathrm{C}$ dates. The well-constrained age model of Lake Soppensee has been subject of several palaeoenvironmental studies providing reconstructions on the terrestrial and limnological ecosystem development on the basis of proxies such as pollen (Lotter, 1999), diatoms (Lotter, 2001), pigments (Züllig, 1989) or stable isotopes (Fischer, 1996). Additionally, there are also studies that investigated the extent of human impact since the Neolithic in the region (Nielsen, 2009; Tinner et al., 2005, 2007). With this extensive data set we aimed to evaluate the dating potential of the long-chain $n$-alkanes, but also to correlate the residence time of long-chain $n$-alkanes in the terrestrial system with changes in the lake or the terrestrial environment, such as vegetation change or human impact.

\section{Methodology}

\subsection{Study site and Sampling}

The investigated lacustrine sediments were recovered from Lake Soppensee situated on the Central Swiss Plateau $\left(8^{\circ} 05^{\prime} \mathrm{E}, 47^{\circ} 05^{\prime} 30^{\prime \prime} \mathrm{N}\right)$ at $596 \mathrm{~m}$ a.s.I. (Fig. 1). It is a small eutrophic hard-water lake formed by dead ice that remained from the retreating Reuss glacier after the last glacial maximum (LGM) around 17-18 ka cal BP ago (Lotter, 1989). The lake has a maximum depth of $27 \mathrm{~m}$ and a surface area of 0.227 $\mathrm{km}^{2}$. There are no major inlets and the lake is fed by groundwater and seasonal surface run-off from the small drainage basin with an area of $1.6 \mathrm{~km}^{2}$. One of the main characteristics of the sediments is a continuous, well-defined annual lamination during the first half of the Holocene (ca. $6.0-11.5 \mathrm{cal} \mathrm{BP}$ ) and a less pronounced 
varved section during the Late Glacial (ca. 11.5-13.0 ka cal BP, Hajdas and Michczynski, 2010; Hajdas et al., 1993).

Samples were obtained from piston cores that were recovered in August 2008 from the deepest part of the lake (van Raden, 2012). The sediment cores (So08-01/2) had a composite length of $\sim 6 \mathrm{~m}$ with organic-rich and partially varved sediments covering the latest Pleistocene and the entire Holocene. Five samples taken across the whole record were selected in order to date the bulk TOC of the sediment and will be labeled as 'Bulk_depth' below. Another set of eight samples dedicated for ${ }^{14} \mathrm{C}$ analysis on individual long-chain $n$-alkanes (Alk_depth) were carefully chosen from either significant marker horizons or from layers containing macrofossils, allowing a direct comparison with a macrofossil ${ }^{14} \mathrm{C}$ age that is the basis for the lake chronology. Finally, five samples for ${ }^{14} \mathrm{C}$ analysis on carbonates $\left(\mathrm{CaCO}_{3}\right.$ depth $)$ were taken from the section with highest $\mathrm{CaCO}_{3}$ concentrations between sediment depths from 436 to $484 \mathrm{~cm}$. Further information about the radiocarbon samples is provided in Table 1.

\subsection{Lithology and bulk sediment parameters}

A detailed description of lithological and sedimentological parameters, as well as photographs of the sediments can be found in earlier publications (Fischer, 1996; Kind et al., 2012; Lotter, 1989; Lotter et al., 1997; van Raden, 2012). Briefly, lithological parameters allowed the division of the sedimentary record into six units (Fig. 2). The oldest part ( $\mathrm{A}$; below $560 \mathrm{~cm}$ ) is characterized by detrital, glacial deposits with low TOC content. Layers with sand and marls fade to silty clays of a light grey towards the boundary to the next unit (ca. 13.8 ka cal BP). From this point the record consists of lacustrine sediments with different appearances. Unit B (500$560 \mathrm{~cm}$ ) is dark brownish and organic-rich, consists mainly of carbonates, silty clays and has faint laminations. The following unit $\mathrm{C}(360-500 \mathrm{~cm})$ is characterized by continuous laminations with annual varves of light colored calcite alternating with dark organic layers. The overall color changes gradually from dark grey at the onset 
of the Holocene, to light beige, and then back to a dark grey (6 ka cal BP). The varves begin to fade in unit $D(170-360 \mathrm{~cm})$ that is rich in organic material. The next unit $E(35-170 \mathrm{~cm})$, which covers most of the last 2000 years, contains homogenous, organic carbon rich sediments. The topmost part of the record (above $35 \mathrm{~cm},<200$ years) is light brown with decreasing TOC and increasing clay contents.

Carbon contents were determined on aliquots from all samples for bulk and alkane dating by coulometric titration using a $\mathrm{CM} 5012 \mathrm{CO}_{2}$ analyzer. Total carbon (TC) was determined by combustion using a $\mathrm{CM} 5200 \mathrm{CO}_{2}$ autosampler, whereas inorganic carbon (TIC) was analyzed with a CM 5130 acidification module (all three manufactured by UIC Inc., Joliet, USA). TOC contents were calculated as the difference between TC and TIC.

In order to gain a better overview of the sedimentary OM content over the entire record, we additionally present previously unpublished data made available by $\mathrm{M}$. Sturm. These analyses were carried out using sediment material from another Soppensee core (So89-23) recovered in 1989 (e.g. Fischer, 1996; Hajdas et al., 1993). TOC and total nitrogen (TN) contents, as well as accumulation rates were determined every $5 \mathrm{~cm}$ (between 0 to $3 \mathrm{~m}$ depth) or every $1 \mathrm{~cm}$ (from 3 to $6 \mathrm{~m}$ depth). The ratio of TOC over TN $(\mathrm{C} / \mathrm{N})$ was used as an indicator for OM sources. Avoiding an underestimation of $\mathrm{C} / \mathrm{N}$ ratios $\mathrm{TN}$ values needed to be corrected for the presence of adsorbed ammonia in the clays of the sediment (Meyers, 1997; Müller, 1977). TN concentrations were corrected for residual $\mathrm{N}$ as follows: $\mathrm{N}^{\prime}=\mathrm{TN}-0.054$ (a cross plot of TOC and TN values is provided in the supplementary information). Within the glacial deposits (deeper than $5.3 \mathrm{~m}$ ) TOC and TN contents were relatively low, and correction for residual $\mathrm{N}$ lead to great uncertainties. Because of this, $\mathrm{C} / \mathrm{N}$ ratios are not shown if TOC contents dropped below 1.5 wt.\%. 


\subsection{Sediment chronology}

An age model for the sampled core So08-01/2 was developed by van Raden (2012). It is mainly based on the published age-depth model of the previously studied core So89-17 (Hajdas et al., 1993; Hajdas and Michczynski, 2010). The re-calibrated chronology for So89-17 was built using the $P$ _Sequence deposition model of OxCal (Bronk Ramsey, 2008) applied to ${ }^{14} \mathrm{C}$ ages of terrestrial macrofossils covering the time between 14.0 and 1.5 ka BP (Hajdas and Michczynski, 2010). The presence of many clear markers and laminations allowed a detailed correlation between the two cores and usage of the given age model. As it was difficult to accurately match the youngest, unlaminated section, four additional terrestrial plant remains were sampled from So08-01/2 and dated. The data were calibrated and modeled using IntCal09 (Reimer et al., 2009) and the $P$ _Sequence deposition model provided with the software OxCal (Bronk Ramsey, 2008).

\subsection{Isolation and preparation for ${ }^{14} \mathrm{C}$ analysis}

Bulk sediment samples were treated with standard acid-base-acid treatment to remove carbonates and humic acid (Hajdas, 2008). The treated samples were weighed (Table 1) into tin capsules; combusted in an elemental analyzer coupled with an automated graphitization equipment (AGE) system (Wacker et al., 2010b). Samples for carbonate dating were placed in $12 \mathrm{ml}$ septum sealed vials and flushed with helium. Carbonates were dissolved in concentrated $\mathrm{H}_{3} \mathrm{PO}_{4}(85 \%)$, vials then were flushed with helium to transport the $\mathrm{CO}_{2}$ to the AGE system (Wacker et al., 2013a). Measuring of ${ }^{14} \mathrm{C} /{ }^{12} \mathrm{C}$ ratios for all samples (Table 1 ) were carried out on a miniaturized radiocarbon dating system (MICADAS, Synal et al., 2007) at the Laboratory of Ion Beam Physics, ETH Zürich.

Individual $n$-alkanes were isolated from the sediment following the laboratory protocol described in Jones et al. (2013). In brief, homogenized and freeze-dried sediments 
(3.7 to $8.8 \mathrm{~g}$ ) were subjected to accelerated solvent extraction with dichloromethane (DCM) and methanol (MeOH) (9:1, v/v) using an ASE 200 system (Dionex, Sunnyvale, USA). The resulting total lipid extracts were separated on $\mathrm{KOH}$ impregnated silica gel columns. First a neutral fraction was recovered with DCM-ethyl ether $(1: 1, v / v)$, from which in turn an apolar fraction, containing the $n$-alkanes, was separated over a regular silica gel column, using hexane. Finally unsaturated hydrocarbons were removed using $\mathrm{AgNO}_{3}$-coated silica gel. Identification and quantification of $n$-alkanes in the sample extracts was performed on an Hewlett Packard (HP) 6890 Series gas chromatography (GC) system equipped with a mass selective (MS) detector (HP 5973), and by comparison of mass spectra and peak areas of an external standard. Isolation of individual $\mathrm{C}_{27}, \mathrm{C}_{29}$ and $\mathrm{C}_{31}$ alkanes was achieved by repetitive injection on a preparative gas chromatography ( $p c G C)$ system. The pcGC consists of an HP 6890 GC fitted with a cooled injection system (Gerstel GmbH, Mülheim an der Ruhr, Germany), a megabore fused silica column (DB-XLB, $30 \mathrm{~m} \times 0.53 \mathrm{~mm}$ i.d.), a flame ionization detector, and a preparative fraction collector (PFC, Gerstel). Individual alkanes accumulated in glass traps attached to the PFC. Quantity and purity of the isolated fractions were determined on the GS/MS system. In order to obtain sufficient amounts of $\mathrm{C}$ for AMS analysis, most of the individual alkanes $\left(\mathrm{C}_{27}, \mathrm{C}_{29}\right.$ or $\left.\mathrm{C}_{31}\right)$ from one sample had to be combined, except for Alk_59, Alk_468 and Alk_502 (Table 1). The isolated samples were transferred to quartz tubes containing pre-combusted $\mathrm{CuO}$, vacuum-sealed and converted to $\mathrm{CO}_{2}$ at $900^{\circ} \mathrm{C}$. Radiocarbon analyses were performed with the MICADAS equipped with a gas ion source (Ruff et al., 2007; L. Wacker et al., 2013b).

All ${ }^{14} \mathrm{C}$ data are reported following the convention of Stuiver and Polach (1977). The measured ${ }^{14} \mathrm{C}$ concentrations were corrected for instrumental background, standard normalization, and evaluation of uncertainties using the software Bats (Wacker et al., 2010a). The isolated $n$-alkanes were additionally corrected for a blank given by the 
laborious chemical extraction and purification process. This processing blank was determined analyzing two standards of known radiocarbon concentration, one modern and one ${ }^{14} \mathrm{C}$-dead. Detailed information about such a routine assessment of extraneous $\mathrm{C}$ addition during the purification process can be found elsewhere (e.g. Gierga et al., 2014; Lang et al., 2013; Santos et al., 2010; Shah and Pearson, 2007). For this study, an average blank of $0.38 \pm 0.10 \mu \mathrm{g} \mathrm{C}$ with $0.34 \pm 0.11 \mathrm{~F}^{14} \mathrm{C}$ was determined (further information about the blank assessment and data correction is provided in the supplementary information).

\section{Results and Discussion}

\subsection{Sources of sedimentary organic matter and hard water effect}

In order to identify processes that control the deposition of either pre-aged or recent compounds, we need to consider the origin of the $\mathrm{OM}$ in relation to the ecosystem development, including both the terrestrial and the aquatic system. According to Fischer (1996), sedimentary TOC concentrations displayed changing TOC accumulation rates between ca. 14.0 and $1.5 \mathrm{ka}$ cal BP (Fig. 3). A general distinction between aquatic and terrestrial biomass can be given by the corrected $\mathrm{C} / \mathrm{N}$ ratios of the sediment (Meyers and Ishiwatari, 1993), where ratios between 4 and 10 are typical for the presence of algae and corrected $\mathrm{C} / \mathrm{N}$ ratios higher than 20 for vascular plants (Meyers, 1994). The detrital glacial deposits older than 14 ka cal BP were characterized by rather low $\mathrm{C} / \mathrm{N}$ ratios between 8 and 9, i.e. most of the $\mathrm{OC}$ was of autochthonous origin. After the transition to authigenic lacustrine deposits at $13.8 \mathrm{ka}$ cal BP TOC and N concentrations slowly increased, and the same was true for $\mathrm{C} / \mathrm{N}$ ratios that reached values higher than 10 . After that the corrected $\mathrm{C} / \mathrm{N}$ ratios fluctuated between 10 and 15 over the main part of the Holocene, implying that the sedimentary $\mathrm{OM}$ was consisting of both aquatic and terrestrial OM. Only during the last 200 years corrected $\mathrm{C} / \mathrm{N}$ values dropped below 9 , however from this section no 
samples were taken for the current study. Overall, sedimentary $\mathrm{TO}^{14} \mathrm{C}$ contents of the dominant part of the record were thus continuously characterized by both contributions of terrestrial $\mathrm{OM}$ and aquatic $\mathrm{OM}$.

The long-chain $n$-alkanes $\left(\mathrm{C}_{27}\right.$ to $\left.\mathrm{C}_{31}\right)$ are one component of that terrestrial $\mathrm{OM}$. The entire $n$-alkane series extracted from Soppensee sediments showed the typical pattern for terrestrial OM with a strong odd-over-even predominance and peak concentrations for alkanes with C chain lengths of 27, 29 or 31 (e.g. Cranwell, 1973; Eglinton and Hamilton, 1967, Fig. 4). Algal or bacterial derived homologues ( $19 \mathrm{C}$ atoms) were partly present in the younger sediments, but only in minor abundance. The summed concentration of the investigated alkanes $\left(\mathrm{C}_{27}, \mathrm{C}_{29}\right.$ and $\left.\mathrm{C}_{31}\right)$ followed the trend of the TOC concentration curve (Fig. 3), thus supporting the evidence that the sedimentary TOC contained a significant amount of terrestrial OM.

There is, however, also some contribution of aquatic-derived OM. The radiocarbon age of this $\mathrm{OM}$ is primarily determined by the local reservoir age, which can be estimated by the radiocarbon content of sedimentary carbonates. The carbonates display an age offset ranging between $610 \pm 180$ and $1220 \pm 180{ }^{14} \mathrm{C}$ years (Table 1 , Fig. 3) resulting in an average reservoir effect of $970 \pm 370{ }^{14} \mathrm{C}$ years. In addition to the carbonates four lake water $\mathrm{DI}^{14} \mathrm{C}$ measurements, performed in 1993 (Table 1) were also available (Hajdas, unpublished), which display an average age offset of $1150 \pm 210{ }^{14} \mathrm{C}$ years compared to the atmospheric ${ }^{14} \mathrm{C}$ content in 1993 (Levin et al., 2008). This is in the range observed in the carbonates deposited between 8.1 and 10.1 ka cal BP (Fig. 3). Although we only have results from between 8.1 to $10.1 \mathrm{ka}$ cal BP, and modern water samples, the consistency of the offset suggests that the 'hard water effect' in the Soppensee has probably been constant over the entire Holocene. 


\subsection{Late Glacial}

Late Glacial samples are covering the Bølling/Allerød (B/A) warm period and the cold Younger Dryas (YD). The comparison of the chronology of this core with other cores from Soppensee studied for pollen (Lotter, 1999) and for stable isotopes (Fischer, 1996), as well as the identification of distinct markers in the cores allowed to determine absolute ages of the periods. According to this the transition from B/A to YD took place at ca. $12.5 \mathrm{ka}$ cal BP. The development of the ecosystem on land initiated just after glacial retreat. The establishment of terrestrial pioneer vegetation during the $\mathrm{B} / \mathrm{A}$ was illustrated in a twofold increase of pollen concentration (e.g. juniper, birch, willow) in the sediment (Lotter, 1999) within that warm phase. However, the landscape still provided limited retention capacity for plant detritus and other accumulating OM. This can explain the maximum in the TOC profile during the B/A (Fig. 3). During the following YD cold phase the ecosystem productivity likely decreased, which is reflected in lower TOC contents. During this period $\mathrm{C} / \mathrm{N}$ ratios had slowly risen from ca. 9 to 11 , indicating that the sedimentary OM was composed of increasing amounts of terrestrial input. TOC deposited during the B/A (Bulk_557, Table 1), shows an age offset of $550 \pm 140$ years. Assuming that the ${ }^{14} \mathrm{C}$ signature of terrestrial component of TOC would not show a significant age offset, because of the youth of the landscape, this implies that aquatically sourced $\mathrm{C}$ exhibited an old ${ }^{14} \mathrm{C}$ signature. Assuming a similar reservoir effect compared to today (1 ka) we can calculate that up to $40 \%$ of the analyzed TOC could be of aquatic origin to obtain the measured offset (details about the mass balance calculation is provided in the supplementary information). However, it is also possible that the local reservoir effect was greater during this time, which was characterized by relatively high accumulation rates in Soppensee (Fischer, 1996; van Raden, 2012). A relatively large amount of exposed, weathering-prone fine-grained detrital carbonate was probably exposed on land freed from the retreating glaciers. In addition, it is also possible that the detrital 
input also contained highly aged terrestrial OC. This old C could have been produced before being covered by ice, and was preserved under the ice until the deglaciation. A similar remobilization of very old $O C$ is currently taking place in the Sub-Arctic region as reported by Vonk et al. (2010).

\subsection{Early and mid Holocene}

During the early Holocene (ca. 11.5 to 9.0 ka cal BP) sediments were continuously laminated with light colored calcite-rich layers alternating with dark organic layers (Fischer, 1996). With increasing temperatures and possibly wetter conditions, ecosystem production increased compared to the YD (Lotter, 1999). Pollen analysis showed that deciduous shrubs and trees were replaced by open woodland of pines and birches (Lotter, 2001) that was present during the YD. The peak TOC concentration up to $20 \%$ at the onset of the Holocene (ca. $10.9 \mathrm{ka}$ cal BP) suggests that this open woodland vegetation had a limited capacity to retain the organic matter in the watershed, resulting in a high $\mathrm{C}$ transport to the lake. With an increasing vegetation coverage OM transport decreased, as is apparent from decreasing sedimentary TOC contents down to about $6 \%$ within ca. $1 \mathrm{ka}$.

The $\mathrm{C}_{27}, \mathrm{C}_{29}$ and $\mathrm{C}_{31}$ n-alkanes of Alk_502 were dated individually instead of a pooled fraction, in order to warrant that the pooling of these $n$-alkanes was justified. Unfortunately, the results carry fairly large uncertainties due to the very small sample size of the alkanes $(<10 \mu \mathrm{g} \mathrm{C})$. Within these errors the values are, however, similar. The weighted average offset of the alkanes from Alk_502 is $560 \pm 930$ years (Table 1, Fig. 3). Although some pre-aging on land thus likely existed, the error of the alkane age is larger than the difference in age between the alkanes and the macrofossils so that both ages cannot be clearly differentiated. The other alkane samples (Alk_488, Alk_468) and the bulk TOC sample (Bulk_478) were sampled from the section that is characterized by decreasing TOC contents. They showed low or no age offset within the given uncertainties (Table 1, Fig. 3). Here, the $C_{27} n$-alkanes of Alk_468 were, 
again, dated individually, while the $\mathrm{C}_{29}$ and $\mathrm{C}_{31}$ were pooled. Similar to Alk_502 the single samples were considerably small leading to relatively large uncertainties, so that no difference in age can be observed. Within this section differences with sediment age are within error, and thus they would fulfill all requirements for the establishment of a chronology.

During the following period of the mid Holocene (ca. 8.5 to 6.0 ka cal BP) TOC accumulation rates and TOC contents increased. The samples Alk_412, Alk_402 and Bulk_416 cover a time range between 7.0 to $7.7 \mathrm{ka}$ cal BP. These sediments were still continuously laminated. The samples showed a slightly increased age offset of $490 \pm 85$ years (Bulk_416), $590 \pm 260$ years (Alk_412) and $290 \pm 160$ years (Alk_402). Interestingly, both TOC and $n$-alkanes show the same age offset. Nevertheless, as we do not know the absolute distribution of terrestrial and aquatic $\mathrm{OC}$, and to which extent both fractions are pre-aged, respectively affected by the hard water effect, we cannot draw a conclusion whether a hard water effect can be neglected or not. However, then the TOC age offset indicates that some erosion of pre-aged terrestrial OC, including $n$-alkanes, was a general feature of the early-mid Holocene, albeit to a limited extent. Assuming that the pre-aged fraction of the $n$ alkanes was produced during the earliest stages of ecosystem development (at ca. $11 \mathrm{ka}$ cal BP), while the rest was of the same age than the sediment, then this would mean that $8 \%$ (Alk_402) to $17 \%$ (Alk_412) of the eroded $n$-alkanes, and by inference of terrestrial $O C$ would need to be pre-aged to explain the observed age offsets (further information about this dual mass balance approach is given in the supplementary). These are minimum estimates, as addition of younger (i.e. less preaged) organic matter would have a smaller effect on the age differential. However, all these values should be taken with care, as the age offset is very small within the range of the uncertainties of both the sediment and the compound age. 
At around $7 \mathrm{ka}$ cal BP the mixed oak forest was replaced by shadow-tolerant firbeech woodland (Lotter, 2001). Within this period the varves began to fade in the sediment, changing towards homogenous dark organic-rich sediment at around 5.9 ka cal BP. Alk_339 was sampled from this homogenous section (5.5 ka cal BP) and its age corresponded very well with the sediment age (120 \pm 160 years offset). The dominance of fir-beech forest lasted in total more than $5 \mathrm{ka}$ until $1.5 \mathrm{ka}$ cal BP. Sedimentary TOC concentrations stayed high and fairly constant at $18-20 \%$ over this period, whereas TOC accumulation rates were relatively low. This indicates very stable conditions of the terrestrial ecosystem where surface runoff likely eroded mainly recently produced terrestrial $\mathrm{OM}$, with only smaller amounts of inorganic material. This agrees with a low age offset of TOC from 4.0 ka cal BP old deposits (Bulk_290; $230 \pm 70$ years offset).

Based on the above, we suggest that terrestrial OM deposited between 11.5 and 4.0 ka cal BP was composed of mainly freshly produced biomass, which was eroded only from the surface of the soils, probably with a limited contribution of pre-aged OM. As follows from the discussion below, part of the OM produced during this period must have been stored in the soil column where it was protected under the closed vegetation cover and escaping surface run-off, allowing the build-up of an increasingly aged OM pool protected from degradation.

\subsection{Late Holocene}

Even though the sediments themselves did not show any significant change compared to older parts, the age offsets of $n$-alkanes and TOC increased significantly at least over the last $3.1 \mathrm{ka}$ (Fig. 3). Alkanes separated from $3.1 \mathrm{ka} \mathrm{cal}$ BP old sediments (Alk_250) were on average $1160 \pm 100$ years older than the sediment. The ${ }^{14} \mathrm{C}$ content of a TOC sample taken from 600 cal BP old sediments (Bulk_83) expressed an average age offset of $1000 \pm 65$ years. Alkanes from 400 cal BP (Alk_59) showed an age offset of as much as $7390 \pm 430$ years $\left(C_{27}\right)$ and of 3570 
\pm 260 years $\left(C_{29}\right.$, Table 1$)$. The large difference of more than 4 ka between the two $n$ alkanes in this sample cannot readily be explained by differential preservation. The large difference may be caused by the very small sample sizes of both samples $\left(\mathrm{C}_{27}\right.$ : $6.5 \mu \mathrm{g} \mathrm{C}$ and $\mathrm{C}_{29}: 5.0 \mu \mathrm{g} \mathrm{C}$ ). Even though a blank contribution has been determined for this procedure, that value still exhibits a scatter of some degree, which is in turn much more significant the smaller the sample size is. We do not assume that both samples are highly affected by contamination, but we cannot clearly identify whether an offset of $7.4 \mathrm{ka}$ or $3.6 \mathrm{ka}$ is more realistic. Yet, both of them clearly show that the age offset is significantly enhanced.

\subsection{Storage and erosion of soil organic matter}

In summary, sedimentary OM consisted during the most part of the Holocene predominantly of recently produced terrestrial compounds, with small contributions of pre-aged terrestrial $\mathrm{OM}$, and only a negligible contribution of aquatic-derived $\mathrm{OM}$. During the last $3.1 \mathrm{ka}$, however, an increasing contribution of significantly pre-aged terrestrial OM to the sedimented OM was observed (Fig. 2). One possibility to explain this feature is that local events such as floods permanently and significantly changed the regime of particle transport to the lake. A possible test for this hypothesis would be to specifically analyze flood events, which could document the transport and erosion of older organic carbon pools. A study of Wirth et al. (2013), for example, did indeed observe an increase of the flood frequency in lake sediments of the Central Alps during the last 2.0 to $2.5 \mathrm{ka}$. Another explanation for the increasing sedimentation of pre-aged OM is increased human activity in the lake catchment. Even though there is evidence of the first human presence at ca. $7 \mathrm{ka}$ cal BP around the lake, a clear influence on the vegetation became only evident at the beginning of the Bronze Age after ca. $4.5 \mathrm{ka}$ cal BP. Larger forest clearings took place enabling intensive land-use and settlements (Tinner et al., 2005). We interpret the high $n$ alkane age offset as a documentation of increased soil erosion due to forest cutting 
and opening. We argue that aged OM that had been stored in soils and protected by a closed vegetation cover became prone to erosion. In order to produce an offset of about 1150 years (Alk_250), ca. $20 \%$ of the alkanes needed to be as old as $11 \mathrm{ka}$ $\mathrm{BP}$ (i.e. pre-aged for $7 \mathrm{ka}$ at the time of deposition) assuming that the remaining $80 \%$ were at the time of sedimentation recently produced alkanes. This mixing model gives the minimum amount of aged $n$-alkanes necessary to explain the offset. The given offset can also be explained with the admixing of $57 \%$ of 5000 -year-old $n$ alkanes or any other age distribution between new and highly pre-aged OM.

Forest down cutting continued during the Iron Age (ca. 2.8 to $2.0 \mathrm{ka}$ cal BP), but the major anthropogenic deforestation inducing drastic changes in the ecosystem took place during the Medieval Age (ca. 1250 to 200 cal BP, Lotter, 1999; Tinner et al. 2005). The very old $n$-alkane ages can be explained by a change from a forest ecosystem to today's open landscape, leading to an even more increased sediment and TOC supply and accumulation. Indeed, during the last $1.5 \mathrm{ka}$ cal BP the deposition of sediments was strongly affected by steeply increasing sediment and TOC accumulation rates (Fischer, 1996) as a result of ongoing forest openings and intensification in agriculture. The missing vegetation cover and periodic ploughing must have remobilized old soil OM stored in the pedosphere. If we assume that the aged fraction of Alk_59 had an average age of 11 ka cal BP, a contribution of at least $49 \%$ pre-aged alkanes ( $\mathrm{C}_{29}$ alkanes) or up to $82 \%\left(\mathrm{C}_{27}\right.$ alkanes $)$ are necessary to explain the offsets. These considerably high offsets emphasize the drastic human impact on the ecosystem that is also shown by strong changes in TOC contents, accumulation rates and $\mathrm{C} / \mathrm{N}$ ratios (Fig. 3). Considering the entire $\mathrm{C}$ cycle in the catchment, this would imply that the build-up of refractory $\mathrm{OM}$ on land, which continued during the early and mid Holocene (11.5 to 3.1 ka cal BP) was dramatically interrupted by anthropogenic pressure and land use change, and that this already started a few thousand years ago. The deposition of increasingly aged terrestrial OM 
since $3.1 \mathrm{ka}$ cal BP shows remobilization of an old, refractory $\mathrm{C}$ pool in the small catchment of Soppensee, that prior to anthropogenic pressure simply remained on land and never made it into the sedimentary record. A similar ongoing build-up of a refractory $\mathrm{C}$ pool in the Holocene was reported in a previous study by Smittenberg et al. (2006), which observed increasing ages of terrestrial biomarkers with decreasing age of sedimentation. In their case this did show up in the sedimentary record, probably due to generally stronger fluvial erosion, which released some of the ageing C pool in the much larger catchment. A similar observation was made by van Vonk et al. (2012), which found a relation between the age of $n$-alkanes deposited off Arctic rivers and the extent of permafrost thawing in the hinterland, i.e. the release of an old C pool with dramatic environmental change. Summarizing, our data confirms the accumulation of a soil OM pool since the last deglaciation during the most part of the Holocene, where physical and/or chemical protection mechanisms must have prevented the decomposition or dislocation of part of the produced biomass. Due to human impact, an ongoing mobilisation of a pre-aged fraction in the soil $\mathrm{OM}$ pool is taking place in the catchment of Soppensee, starting at the latest at 3100 year ago. However, the abrupt increase of the amount of pre-aged matter during the last millenia suggests that the aged fraction in soils is continously being depleted and most likely the inventory of the entire soil OM pool, as well. With the available data, it is not possible to determine whether the pre-aged $\mathrm{OM}$ is still being build-up on land or whether erosion rates are exeeding deposition, resulting in a net carbon depletion of of terrestrial OM. In order to investigate this, a study with higher resolution would be necessary.

\subsection{Implication for chronological applications of compound-specific} radiocarbon dating in lake sediments

For the main part of the Holocene and Late Glacial, long-chain $n$-alkanes appear to be reasonably suitable for chronological purposes. Despite changes in vegetation 
documented by the pollen record, illustrating an initial succession towards a forest ecosystem with a subsequent change from a dominance of oaks to a fir-beech wood, the $n$-alkanes do not show large change in residence time. The continuous vegetation cover appears to have helped protect soil organic matter against erosion by water or wind, leaving surface runoff of relatively fresh litter and aeolian transport of leaves and leaf waxes to be the main modes of organic matter transport to the lake. We suggest that this situation would have continued until the present if no major disturbances through human activity had occurred. Theses mechanisms are especially valid for lakes with a small watershed and limited surface runoff like Soppensee, and confirms the findings of Uchikawa et al. (2008) and Jones et al. (2013). The latter authors successfully used CSRA on $n$-alkanes to refine a badly constrained chronology for sediments older than ca. 3.0 to $3.5 \mathrm{ka}$ cal BP, a period in which the terrestrial ecosystem was not yet greatly affected by human activity. In this study the ages of sedimentary TOC do show a certain offset to the sediment age, except for one sample (bulk_478). However, due to the high proportion of terrestrial derived OM and the relatively small 'hard water effect' of less than 1000 years it is not possible to clearly distinguish whether this offset is caused by the hard water effect or a pre-aging of the terrestrial components. Most likely it is a combination of both. Therefore, in hard water lakes we do recommend using ${ }^{14} \mathrm{C}$ analysis of terrestrial biomarkers for chronological purposes above bulk sediment dating. Obviously, in lakes without carbonates in the watershed, aquatic-derived biomarkers will only show a minor hard-water effect, and can again be considered superior to terrestrial biomarkers, as a pre-aging can be excluded for these compounds.

Our study does clearly indicates that anthropogenic disturbances led to a remobilization of organic material that had been stored in the soils of the surrounding catchment of lake Soppensees. This already initiated at a very early stage of human 
activity in that region during a period where TOC accumulation rates still seemed to have been unaffected by anthropogenic disturbances. Therefore, we recommend using further independent age markers to accompany and support any biomarkerbased age model. Finally, we strongly recommend aiming for sample sizes large enough (more than $20 \mu \mathrm{g} \mathrm{C}$ ) to ensure obtaining relatively precise ages.

\section{Conclusion}

We investigated the potential of CSRA for chronological purposes and simultaneously examined the implications of ${ }^{14} \mathrm{C}$ contents of specific compounds for the reconstruction of $\mathrm{C}$ cycles and ecosystem development within small catchment areas. Our study shows that the ${ }^{14} \mathrm{C}$ age of molecular markers from terrestrial plants can be used for dating purposes, except when human activities induced drastic changes in land use in the watershed leading to the reworking of old organic carbon from the soils. In absence of such disturbance, absence of major fluvial inputs and a relative flat landscape lead to surface erosion and deposition of dominantly freshly produced terrestrial biomass in the lake, which is the main prerequisite for chronological applications. Therefore CSRA on terrestrial biomarkers can be used for chronological purposes if macrofossils are not or barely present and if the investigated record is not affected by profound changes in the ecosystem (especially human impact). These constraints can be additionally verified using other less costintensive parameters such as accumulation rates, pollen data or possibly existing historical studies.

Aside from the chronological aspect, we can conclude that CSRA on terrestrial biomarkers is a powerful tool to reconstruct the accumulation and evolution of the terrestrial $\mathrm{C}$ cycle through time. The anthropogenic impact in particular allowed us to conclude that a continuous accumulation of refractory OM took place in the catchment soils during the Holocene until human settlement. An increasing 
accumulation of increasingly aged $\mathrm{OM}$ in the lake indicates that this protected $\mathrm{C}$ pool on land decreased during the last 3.1 ka due to reduced capacities of storage and physical protection in the ecosystem.

\section{Acknowledgements}

We acknowledge Axel Birkholz, Robert Hofmann und Samuel Jaccard for help with the sediment coring; Andy Lotter for providing information on the marker horizons; Axel Birkholz, Mantana Maurer and Simon Fahrni for assistance and technical support in the AMS laboratories. Special thanks to Bernhard Pfyffer and Rudolf Studhalter for the permission to core Lake Soppensee.

We also acknowledge the Financial support from Swiss National Science Foundation (SNF) project Nr 200021-119950 / 200020-13484 and Nr 200020-131922 and from Competence Center Environment and Sustainability (CCES) of the ETH domain through the Project BigLink. 


\section{References}

Benoit, G.J., Turekian, K.K., Benninger, L.K., 1979. Radiocarbon dating of a core from Long-Island sound. Estuarine and Coastal Marine Science 9, 171-180.

Bronk Ramsey, C., 2008. Deposition models for chronological records. Quaternary Science Reviews 27, 42-60.

Cranwell, P., 1973. Chain-length distribution of $n$-alkanes from lake sediments in relation to post-glacial environmental change. Freshwater Biology 3, 259-265.

Deevey, E.S., Gross, M.S., Hutchinson, G.E., Kraybill, H.L., 1954. The natural ${ }^{14} \mathrm{C}$ contents of materials from hard-water lakes. Proceedings of the National Academy of Sciences of the United States of America 40, 285-288.

Douglas, P.M.J., Pagani, M., Eglinton, T.I., Brenner, M., Hodell, D.A., Curtis, J.H., Ma, K.F., Breckenridge, A., 2014. Pre-aged plant waxes in tropical lake sediments and their influence on the chronology of molecular paleoclimate proxy records. Geochimica et Cosmochimica Acta 141, 346-364.

Drenzek, N.J., Montlucon, D.B., Yunker, M.B., Macdonald, R.W., Eglinton, T.I., 2007. Constraints on the origin of sedimentary organic carbon in the Beaufort Sea from coupled molecular ${ }^{13} \mathrm{C}$ and ${ }^{14} \mathrm{C}$ measurements. Marine Chemistry 103 , 146-162.

Eglinton, G., Hamilton, R.J., 1967. Leaf epicuticular waxes. Science 156, 1322-1335.

Eglinton, T.I., Aluwihare, L.I., Bauer, J.E., Druffel, E.R.M., McNichol, A.P., 1996. Gas chromatographic isolation of individual compounds from complex matrices for radiocarbon dating. Analytical Chemistry 68, 904-912.

Eglinton, T.I., BenitezNelson, B.C., Pearson, A., McNichol, A.P., Bauer, J.E., Druffel, E.R.M., 1997. Variability in radiocarbon ages of individual organic compounds from marine sediments. Science 277, 796-799.

Fischer, A., 1996. Isotopengeochemische Untersuchungen $\left(\delta^{18} \mathrm{O}\right.$ und $\left.\delta^{13} \mathrm{C}\right) \mathrm{im}$ Wasser und in den Sedimenten des Soppensees (Kt. Luzern, Schweiz). ETH Zürich Diss. Nr. 11924, Zürich, http://dx.doi.org/10.3929/ethz-a-001755548.

Galy, V., Eglinton, T., 2011. Protracted storage of biospheric carbon in the GangesBrahmaputra basin. Nature Geoscience 4, 843-847.

Gierga, M., Schneider, M.P.W., Wiedemeier, D.B., Lang, S.Q., Smittenberg, R.H., Hajdas, I., Bernasconi, S.M., Schmidt, M.W.I., 2014. Purification of fire derived markers for $\mu \mathrm{g}$ scale isotope analysis $\left(\delta^{13} \mathrm{C}, \Delta^{14} \mathrm{C}\right)$ using high performance liquid chromatography (HPLC). Organic Geochemistry 70, 1-9.

Gruber, N., Wehrli, B., Wuest, A., 2000. The role of biogeochemical cycling for the formation and preservation of varved sediments in Soppensee (Switzerland). Journal of Paleolimnology 24, 277-291.

Hajdas, I., 2008. Radiocarbon dating and its applications in Quaternary studies. E \& G - Quaternary Science Journal 57, 2-24.

Hajdas, I., Bonani, G., Goslar, T., 1995. Radiocarbon dating the Holocene in the Gosciaz Lake floating varve chronology. Radiocarbon 37, 71-74. 
Hajdas, I., Ivy, S.D., Beer, J., Bonani, G., Imboden, D., Lotter, A.F., Sturm, M., Suter, M., 1993. AMS radiocarbon dating and varve chronology of Lake Soppensee 6000 to $12000{ }^{14} \mathrm{C}$ years BP. Climate Dynamics 9, 107-116.

Hajdas, I., Michczynski, A., 2010. Age-depth model of lake Soppensee (Switzerland) based on the high-resolution ${ }^{14} \mathrm{C}$ chronology compared with varve chronology. Radiocarbon 52, 1027-1040.

Hou, J.Z., Huang, Y.S., Brodsky, C., Alexandre, M.R., McNichol, A.P., King, J.W., Hu, F.S., Shen, J., 2010. Radiocarbon Dating of Individual Lignin Phenols: A New Approach for Establishing Chronology of Late Quaternary Lake Sediments. Analytical Chemistry 82, 7119-7126.

Jones, T.D., Lawson, I.T., Reed, J.M., Wilson, G.P., Leng, M.J., Gierga, M., Bernasconi, S.M., Smittenberg, R.H., Hajdas, I., Bryant, C.L., Tzedakis, P.C., 2013. Diatom-inferred late Pleistocene and Holocene palaeolimnological changes in the loannina basin, northwest Greece. Journal of Paleolimnology 49, 185-204.

Kind, J., van Raden, U.J., García-Rubio, I., Gehring, A.U., 2012. Rock magnetic techniques complemented by ferromagnetic resonance spectroscopy to analyse a sediment record. Geophysical Journal International 191, 51-63.

Lang, S.Q., Früh-Green, G.L., Bernasconi, S.M., Wacker, L., 2013. Isotopic $\left(\delta^{13} C\right.$, $\Delta^{14} \mathrm{C}$ ) analysis of organic acids in marine samples using wet chemical oxidation. Limnology and Ocenography: Methods 11, 161-175.

Levin, I., Hammer, S., Kromer, B., Meinhardt, F., 2008. Radiocarbon observations in atmospheric $\mathrm{CO}_{2}$ : Determining fossil fuel $\mathrm{CO}_{2}$ over Europe using Jungfraujoch observations as background. Science of The Total Environment 391, 211-216.

Lotter, A.F., 1989. Evidence of annual layering in Holocene sediments of Soppensee, Switzerland. Aquatic Sciences 51, 19-30.

Lotter, A.F., Merkt, J., Sturm, M. 1997. Differential sedimentation versus coring artifacts: a comparison of two widely used piston-coring methods. Journal of Paleolimnology 18, 75-85.

Lotter, A.F., 1999. Late-glacial and Holocene vegetation history and dynamics as shown by pollen and plant macrofossil analyses in annually laminated sediments from Soppensee, central Switzerland. Vegetation History and Archaeobotany 8, 165-184.

Lotter, A.F., 2001. The palaeolimnology of Soppensee (Central Switzerland), as evidenced by diatom, pollen, and fossil-pigment analyses. Journal of Paleolimnology 25, 65-79.

Meyers, P.A., 1994. Preservation of elemental and isotopic source identification of sedimentary organic matter. Chemical Geology 114, 289-302.

Meyers, P.A., 1997. Organic geochemical proxies of paleoceanographic, paleolimnologic, and paleoclimatic processes. Organic Geochemistry 27, 213 250.

Meyers, P.A., Ishiwatari, R., 1993. Lacustrine organic geochemistry - an overview of indicators of organic-matter sources and diagenesis in lake-sediments. Organic Geochemistry 20, 867-900. 
Mollenhauer, G., Inthorn, M., Vogt, T., Zabel, M., Sinninghe Damsté, J.S., Eglinton, T.I., 2007. Aging of marine organic matter during cross-shelf lateral transport in the Benguela upwelling system revealed by compound-specific radiocarbon dating. Geochemistry Geophysics Geosystems 8, Q09004.

Mollenhauer, G., Rethemeyer, J., 2009. Compound-specific radiocarbon analysis: analytical challenges and applications. IOP Confererence Series: Earth and Environmental Science 5, 012006.

Müller, P., 1977. C/N ratios in Pacific deep-sea sediments: Effect of inorganic ammonium and organic nitrogen compounds sorbed by clays. Geochimica et Cosmochimica Acta 41, 765-776.

Ohkouchi, N., Eglinton, T.I., Hayes, J.M., 2003. Radiocarbon dating of individual fatty acids as a tool for refining Antarctic margin sediment chronologies. Radiocarbon $45,17-24$.

Pearson, A., Eglinton, T.I., 2000. The origin of $n$-alkanes in Santa Monica Basin surface sediment: a model based on compound-specific $\Delta^{14} \mathrm{C}$ and $\delta^{13} \mathrm{C}$ data. Organic Geochemistry 31, 1103-1116.

Ruff, M., Wacker, L., Gäggeler, H.W., Suter, M., Synal, H.A., Szidat, S., 2007. A gas ion source for radiocarbon measurements at $200 \mathrm{kV}$. Radiocarbon 49, 307-314.

Santos, G.M., Southon, J.R., Drenzek, N.J., Ziolkowski, L.A., Druffel, E., Xu, X., Zhang, D., Trumbore, S., Eglinton, T.I., Hughen, K.A., 2010. Blank Assessment for Ultra-Small Radiocarbon Samples: Chemical Extraction and Separation versus AMS, in: Radiocarbon. pp. 1322-1335.

Shah, S.R., Pearson, A., 2007. Ultra-microscale (5-25 $\mu \mathrm{g} \mathrm{C)}$ analysis of individual lipids by ${ }^{14} \mathrm{C}$ AMS: Assessment and correction for sample processing blanks. Radiocarbon 49, 69-82.

Shotton, F.W., 1972. An Example of Hard-Water Error in Radiocarbon Dating of Vegetable Matter. Nature 240, 460-461.

Smittenberg, R.H., Eglinton, T.I., Schouten, S., Sinninghe Damsté, J.S., 2006. Ongoing buildup of refractory organic carbon in boreal soils during the Holocene. Science 314, 1283-6.

Smittenberg, R.H., Hopmans, E.C., Schouten, S., Hayes, J.M., Eglinton, T.I., Sinninghe Damsté, J.S., 2004. Compound-specific radiocarbon dating of the varved Holocene sedimentary record of Saanich Inlet, Canada. Paleoceanography 19, PA2012.

Stuiver, M., Polach, H.A., 1977. Discussion: Reporting of ${ }^{14} \mathrm{C}$ data. Radiocarbon 19, 355-363.

Synal, H.A., Stocker, M., Suter, M., 2007. MICADAS: A new compact radiocarbon AMS system. Nuclear Instruments and Methods in Physics Research Section B: Beam Interactions with Materials and Atoms 259, 7-13.

Tinner, W., Conedera, M., Ammann, B., Lotter, A.F., 2005. Fire ecology north and south of the Alps since the last ice age. The Holocene 15, 1214-1226.

Törnqvist, T.E., De Jong, A.F.M., Oosterbaan, W.A., van der Borg, K., 1992. Accurate dating of organic deposits by $A M S{ }^{14} \mathrm{C}$ measurements of macrofossils. 
Radiocarbon 34, 566-577.

Turney, C.S.M., Coope, G.R., Harkness, D.D., Lowe, J.J., Walker, M.J.C., 2000. Implications for the Dating of Wisconsinan (Weichselian) Late-Glacial Events of Systematic Radiocarbon Age Differences between Terrestrial Plant Macrofossils from a Site in SW Ireland. Quaternary Research 53, 114-121.

Uchida, M., Shibata, Y., Kawamura, K., Kumamoto, Y., Yoneda, M., Ohkushi, K., Harada, N., Hirota, M., Mukai, H., Tanaka, A., Kusakabe, M., Morita, M., 2000. Compound-specific radiocarbon ages of fatty acids in marine sediments from the western North Pacific. Radiocarbon 43, 949-956.

Uchikawa, J., Popp, B.N., Schoonmaker, J.E., Xu, L., 2008. Direct application of compound-specific radiocarbon analysis of leaf waxes to establish lacustrine sediment chronology. Journal of Paleolimnology 39, 43-60.

van Raden, U.J., 2012. High-resolution Swiss lake records of climate change. ETH Zurich, Diss. No. 20596, Zürich, http://dx.doi.org/10.3929/ethz-a-009783578.

Vonk, J.E., Alling, V., Rahm, L., Mörth, C.-M., Humborg, C., Gustafsson, Ö., 2012. A centennial record of fluvial organic matter input from the discontinuous permafrost catchment of Lake Torneträsk. Journal of Geophysical Research: Biogeosciences 117, G03018.

Vonk, J.E., van Dongen, B.E., Gustafsson, Ö., 2010. Selective preservation of old organic carbon fluvially released from sub-Arctic soils. Geophysical Research Letters 37, L11605.

Wacker, L., Christl, M., Synal, H.A., 2010a. Bats: a new tool for AMS data reduction. Nuclear Instruments and Methods in Physics Research Section B: Beam Interactions with Materials and Atoms 268, 976-979.

Wacker, L., Němec, M., Bourquin, J., 2010b. A revolutionary graphitisation system: Fully automated, compact and simple. Nuclear Instruments and Methods in Physics Research Section B: Beam Interactions with Materials and Atoms 268, 931-934.

Wacker, L., Fülöp, R.-H., Hajdas, I., Molnár, M., Rethemeyer, J., 2013a. A novel approach to process carbonate samples for radiocarbon measurements with helium carrier gas. Nuclear Instruments and Methods in Physics Research Section B: Beam Interactions with Materials and Atoms 294, 214-217.

Wacker, L., Fahrni, S.M., Hajdas, I., Molnar, M., Synal, H.-A., Szidat, S., Zhang, Y.L., $2013 \mathrm{~b}$. A versatile gas interface for routine radiocarbon analysis with a gas ion source. Nuclear Instruments and Methods in Physics Research Section B: Beam Interactions with Materials and Atoms 294, 315-319.

Wirth, S.B., Glur, L., Gilli, A., Anselmetti, F.S., 2013. Holocene flood frequency across the Central Alps - solar forcing and evidence for variations in North Atlantic atmospheric circulation. Quaternary Science Reviews 80, 112-128. 


\section{Figure Captions}

Figure 1: Map of Switzerland illustrating the location of Soppensee (above) and the shape of the catchment area including a bathymetric map of the lake (right) after Lotter (1989) with the coring location at the deepest part of the lake basin.

Figure 2: Comparison of the radiocarbon ages of different types of C-bearing material against the calibrated age model. Macrofossils (Hajdas and Michczynski, 2010; van Raden, 2012) are displayed in light grey triangles; dates of bulk samples are given in grey squares. Black filled circles represent the ages of combined $\mathrm{C}_{27} / \mathrm{C}_{29}$ - and $\mathrm{C}_{31}$-alkanes. If available, values of individual alkanes are given in light grey-filled triangles. Carbonate samples are shown as diamonds. If not shown, error bars are smaller than the symbols. The lithology of So08-01/2 with a depth scale is illustrated on the right.

Figure 3: Age offsets from TOC, carbonates and alkanes relative to the age of deposition in comparison to the relative alkane concentration within the TOC pool, as well as per g sediment, TOC concentration and accumulation rates, $\mathrm{C} / \mathrm{N}$ ' ratios and key points during ecosystem development after Lotter (2001) (left to right).

Figure 4: Carbon chain length distribution of extracted $n$-alkanes series. 


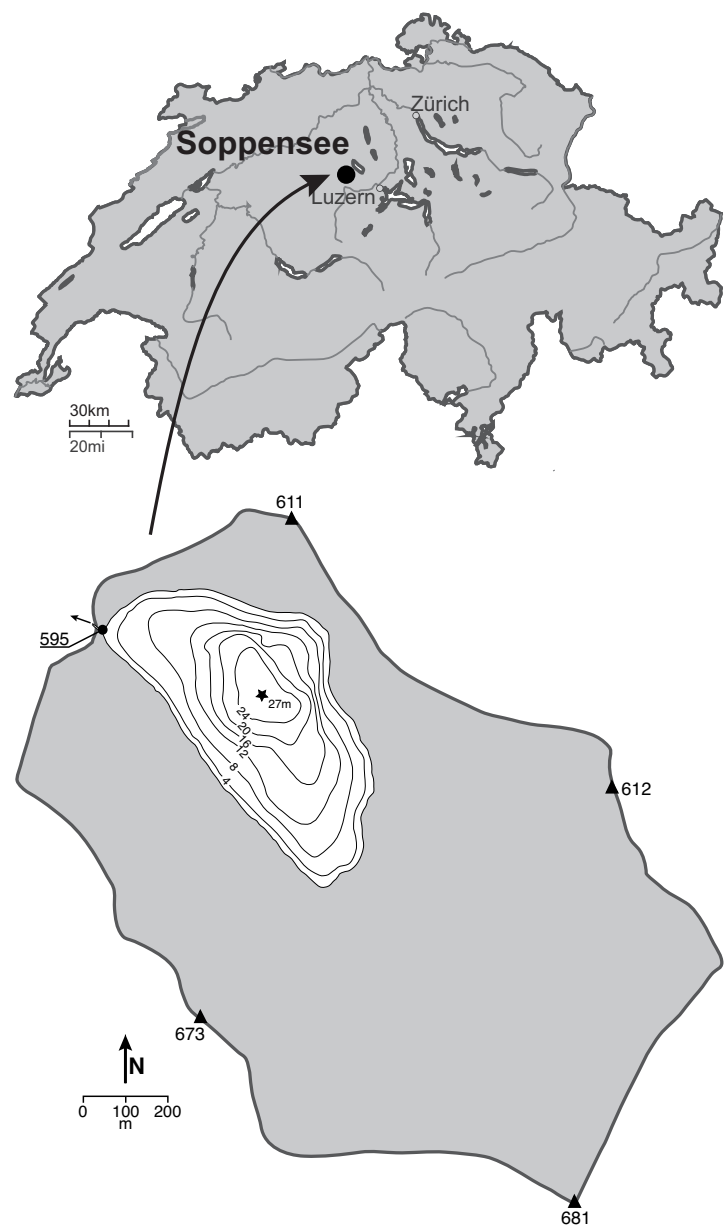




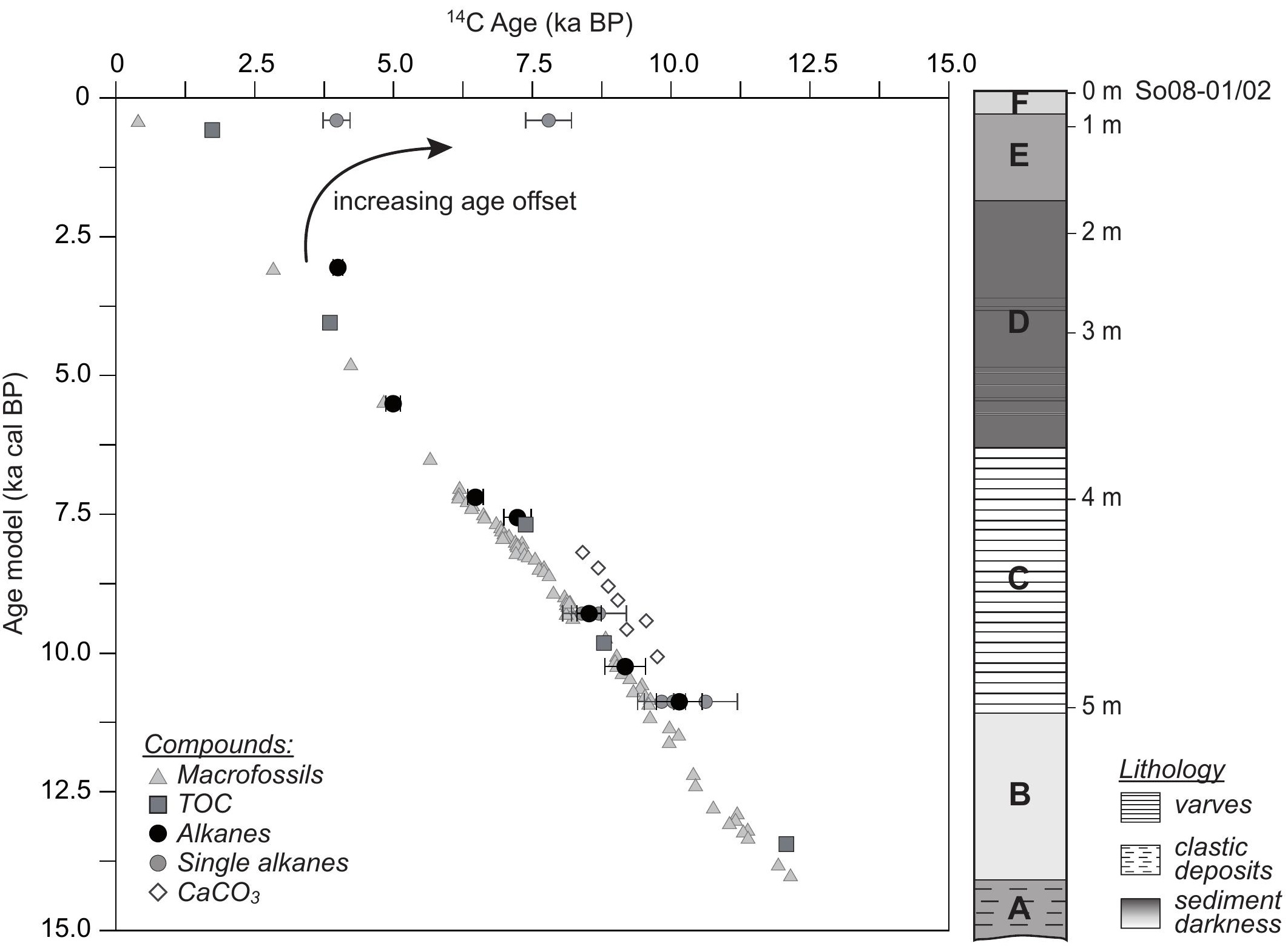




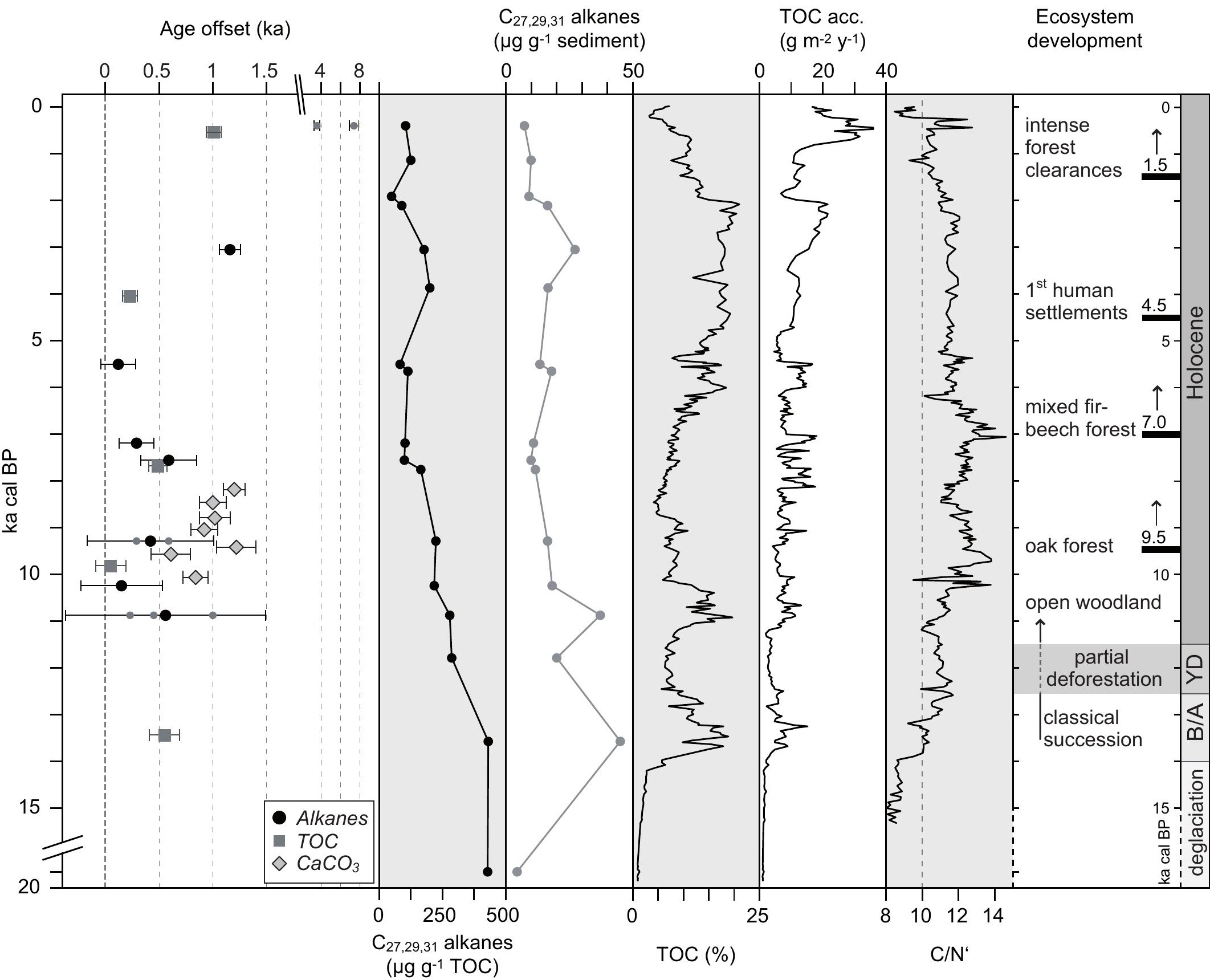


Figure4

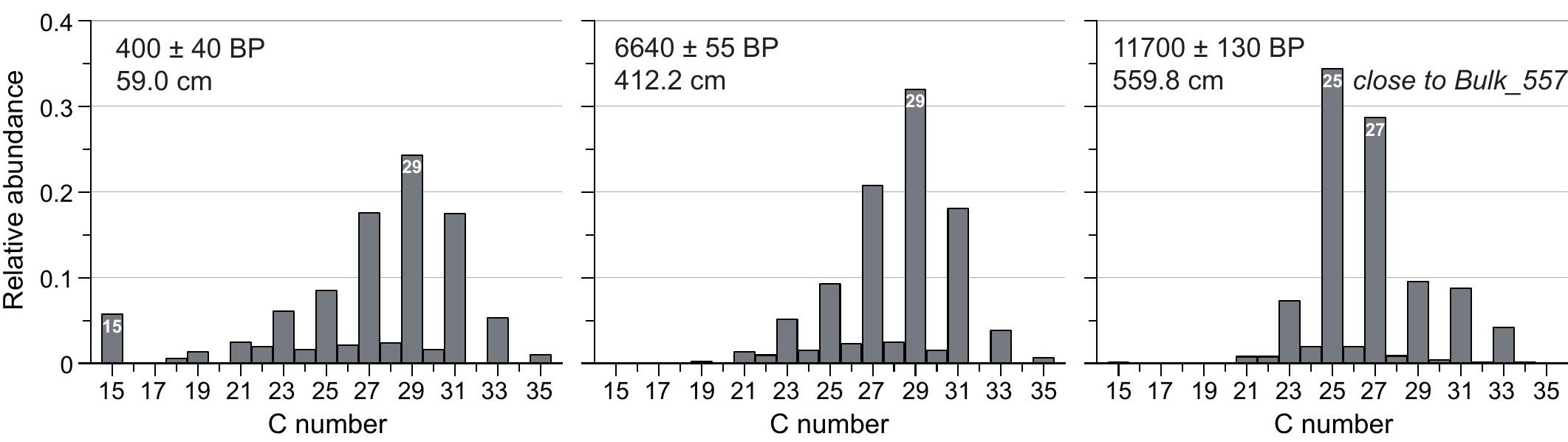

